\section{Postgraduate Education for General Practitioners}

A RIDDLE which puzzles all those concerned with the maintenance of standards of general practice is why more than 70 per cent of the general practitioners in England and Wales undertake no form of postgraduate education. Some general practitioners feel that they can keep up to date by their contacts with fellow-practitioners or consultants or by reading. Others think that the postgraduate courses offered to them are not satisfactory. There are many, however, whose reasons for avoiding postgraduate courses are far from clear, and, to help them, a conference was arranged by the British Postgraduate Medical Federation and the Metropolitan and Home Counties Faculties of the College of General Practitioners. The eight opening papers of the conference have now been published in a recent issue of The Practitioner (185, No. 1109 ; November 1960). With the exception of Dr. H. G. MeGregor, who is adviser on postgraduate education to the South-eastern Metropolitan Hospital Region, the contributors are all general practitioners. The papers represent an authoritative review of what general practitioners feel they require if postgraduate courses are to be of real value. A general conclusion is that the formal lecture should now have little place in the education of the general practitioner, who should play an active part in all postgraduate courses.

\section{History of Science in Poland}

IN December 1958, a plenary meeting of the History of Science Committee of the Polish Academy of Sciences decided that a concise outline of the history of science in Poland should be prepared. In character and level, it is to be a university text-book, emphasizing general aspects of science, conditions of development, organization of scientific work, and the trends in scientific thought which are common to various disciplines. Specific sections will be devoted to the development of various branches of science and the more eminent personalities and their work in Poland. The sections devoted to specialized subjects in particular periods are to be as succinct as practicable, and to embody the maximum possible volume of information. A tentative plan is discussed in the January-March issue of The Review of the Polish Academy of Sciences (5, No. I (17); 1960).

\section{Salvage : Waste or Wealth}

ALtHOOGH it is well known that one industry's waste may be the raw material for another, it is equally well recognized that many firms have found themselves in difficulties because their waste costs have been too high and because they have been unable to make a saleable commodity from their wastes. In the first of a new series designed to be of practical use to industrial management, the Department of Scientific and Industrial Research has produced a booklet which, properly used, could mean the difference between success and failure for many struggling organizations. The booklet, "Waste or Wealth," by Clement Brown, is a collection of stories which show how, by research or technical aid, many industrial wastes are being turned to profit (Pp. 27. London: H.M. Stationery Office, 1960). There are still serious cases of unclaimed wastes-several million gallons of paint are lost each year during spraying; little attempt is being made to make use of scrap leather and a fresh application is needed; a new use for sugar, now produced in excess of demand, is being investigated and could form the basis of a detergent. The booklet's stories of success should spur the inventiveness of management. It may be obtained free of charge from the Department of Scientific and Industrial Research Lending Library Unit, 20 Chester Terrace, London, N.W.I. Readers will wish to commend the Department for the earthy and practical way in which the booklet has been presented and for choosing Peter Kneebone to add those humorous illustrations which tell vivid stories without words.

\section{The British Society for International Understanding}

THE annual report for 1960 of the British Society for International Understanding, presented to the twenty-first annual general meeting on November 16, 1960 , notes that the Society has now published some 600 British Survey pamphlets (Pp. 10. London: The British Society for International Understanding, 1960). These pamphlets have been written by experts and each is devoted to the distinct characteristics of a single Commonwealth or foreign country or to some well-defined international topic. Much of the energies of the staff is now directed to building up and main. taining the Atlantic Treaty Organization and its United Kingdom branch, the British Atlantic Committee. Lord Bessborough, the chairman of the governing body, has suggested that the time has come to give the same special attention to the cultivation of good relations and mutual understanding between Britain and the emergent nations of Africa. The report includes details of publications during the year and of the activities of both the Atlantic Treaty Association and the British Atlantic Committee.

\section{Aeronautical Research in Australia}

THE annual report for 1958-59 of the Aeronautical Research Laboratories of the Australian Defence Scientific Service has recently become available (Pp. 39. Melbourne: Department of Supply, Aeronautical Research Laboratories, 1960). The report is a well-illustrated booklet of thirty-nine quarto pages which record recent progress in research and development, and is refreshingly devoid of 'propaganda'. The research undertaken is relevant either to Australian and Commonwealth defence, or to Australian industry and national development. It is distributed between the various divisions, aerodynamics, structures, materials and mechanical engineering, and covers a very wide range of problems. Since guided weapons are finding wider and wider application and since Woomera, the Commonwealth test-range, is at hand, there is great emphasis on missiles and missile propulsion. A co-ordinated team specializing in this field is suggested. Nevertheless, there is much that concerns current military and civil aircraft. Some interesting work on the fatigue life of aircraft structures is reported-including an investigation aimed at providing a method for the experimental verification of the 'fail-safe structure' so often claimed by designers. There is also the work of the human engineering group on the piloting problems during landing. In an appendix are listed 44 reports and notes dealing with major research projects and the $\mathbf{3 6}$ technical memoranda on minor and ad hoc investigations. Altogether an interesting year's work.

\section{Rock Carvings in Central Australia}

THE October issue of Man contains an interesting article recording some simple rock carvings at 